\title{
Morphological, molecular and phylogenetic characterization of Borrelia theileri in Rhipicephalus microplus
}

\author{
Caracterização morfológica, molecular e filogenética de Borrelia theileri em Rhipicephalus microplus \\ Matheus Dias Cordeiro ${ }^{1}$; Michele Bahia ${ }^{1}$; Paulo Cesar Magalhães-Matos ${ }^{1}$; Marcio Barizon Cepeda ${ }^{1}$; \\ Alexandro Guterres²; Adivaldo Henrique Fonseca ${ }^{1 *}$
}

${ }^{1}$ Programa de Pós-graduaçăo em Ciências Veterinárias, Universidade Federal Rural do Rio de Janeiro - UFRRJ, Seropédica, RJ, Brasil
${ }^{2}$ Laboratório de Hantaviroses e Rickettsioses, Instituto Oswaldo Cruz, Fundaçăo Oswaldo Cruz - FIOCRUZ, Rio de Janeiro, RJ, Brasil

Received August 1, 2018

Accepted October 8, 2018

\begin{abstract}
This study aimed to perform a morphological, molecular and phylogenetic characterization of Borrelia theileri obtained from infected Rhipicephalus microplus in Brazil. Fifty engorged $R$. microplus females from cattle in the municipality of Seropédica, Rio de Janeiro, were analyzed for spirochetes by hemolymph smear. Macerated eggs and positive ticks, as well as blood from the bovine infested by these ticks, were analyzed the $g l p Q, f l a B$ and $h p t$ genes by PCR. The PCR products were purified and sequenced for analysis and construction of a phylogenetic tree. Only $2 \%(1 / 50)$ of the ticks generated a positive result by both smear and PCR. The spiral forms $(n=50)$ had (media \pm SD) a mean length of $19.17 \pm 4.12 \mu \mathrm{m}$, diameter of $0.2935 \pm 0.0469$ and number of turns $8.44 \pm 2.59$. Sequence alignments of the three evaluated genes exhibited $98 \%$ similarity to $B$. theileri isolates, occurring in a clade highly related to $B$. theileri strain KAT. Egg maceration samples were positive for the three evaluated genes, whereas bovine blood was negative by PCR. This is the most detailed characterization of $B$. theileri in the Americas to-date, presenting morphological, molecular and phylogenetic data, including the transovarial transmission of the spirochete in the host tick.
\end{abstract}

Keywords: Relapsing fever-like, Borrelia, Ixodidae, phylogenetic characterization.

\section{Resumo}

O estudo teve como objetivo realizar a caracterizaçáo morfológica, molecular e filogenética de Borrelia theileri obtida de Rhipicephalus microplus naturalmente infectado em bovino no estado do Rio de Janeiro, Brasil. Um total de 50 fêmeas de $R$. microplus ingurgitadas foram analisadas para espiroquetas por meio de esfregaço de hemolinfa. Ovos macerados e carrapatos, assim como sangue de bovinos infectados por esses carrapatos, foram analisados os genes $g l p Q$, $f l a B$ e $h p t$ por PCR. Os produtos de PCR foram purificados e sequenciados para análise e construção de uma árvore filogenética. Apenas 2\% (1/50) dos carrapatos geraram um resultado positivo tanto pelo esfregaço como pela PCR. As formas espirais $(\mathrm{n}=50)$ apresentaram (média $\pm \mathrm{DP})$ comprimento médio de 19,17 \pm 4,12, diâmetro de 0,2935 $\pm 0,0469$ e número de voltas de $8,44 \pm 2,59$. Os alinhamentos das sequências dos três genes avaliados exibiram $98 \%$ de similaridade aos isolados de $B$. theileri, ocorrendo em um clado altamente relacionado à linhagem de B. theileri KAT. As amostras de maceração de ovos foram positivas para os três genes avaliados, enquanto o sangue bovino foi negativo pela PCR. Esta é a mais completa caracterização de $B$. theileri nas Américas, apresentando dados morfológicos, moleculares e filogenéticos, incluindo a transmissão transovarial da espiroqueta no carrapato hospedeiro.

Palavras-chave: Febre recorrente, Borrelia, Ixodidae, caracterização filogenética.

\section{Introduction}

Species in the phylum Spirochaetes (order: Spirochaetales) are thin, spiral-shaped or wave-like, highly motile bacteria that are visualized by darkfield microscopy.

${ }^{*}$ Corresponding author: Adivaldo Henrique Fonseca. Departamento de Epidemiologia e Saúde Pública, Instituto de Veterinária, Universidade Federal Rural do Rio de Janeiro - UFRRJ, Campus de Seropédica, BR 465, Km 7, Bairro Ecologia, CEP 23891-000, Seropédica, RJ, Brasil. e-mail: adivaldofonseca@yahoo.com
Borrelia theileri is a tick-borne spirochete known to infect cattle and other mammals like horse, sheep, and deer. In cattle, the infection can be characterized by fever, lethargy and anemia. This agent is particularly important because $B$. theileri infection induces cross-reactive antibodies that can interfere with the interpretation of seroepidemiological studies of other bovine spirochetes (ROGERS et al., 1999). 
The subclinical aspects of $B$. theileri infection were described by Rogers et al. (1999) and Guedes et al. (2008). This species of spirochete is one of the least-described pathogenic tick-borne Borreliae. Historically, this spirochete has been identified in Africa, Australia, and North and South America (MCCOY et al., 2014). In southeast Brazil, Yparraguirre et al. (2007) detected a Rhipicephalus microplus tick infected with Borrelia sp. strain BR, which was highly correlated with $B$. theileri and $B$. lonestari. Therefore, this study aimed to characterize the morphological, molecular and phylogenetic features of a $B$. theileri isolate obtained from naturally infected $R$. microplus in Brazil.

\section{Materials and Methods}

\section{Ticks and hemolymph smears and examination}

Rhipicephalus microplus ticks of the Porto Alegre strain free of Babesia spp. and Anaplasma spp. kindly provided by Dr. Itabajara da Silva Vaz Junior of the Universidade Federal do Rio Grande do Sul in December, 2014 (RECK et al., 2009). The ticks were maintained for two generations (January and March, 2015) on infested apparently healthy bovines (Bos taurus), Babesia spp. and Anaplasma spp. free. The animals were acquired from the dairy cattle sector of the Universidade Federal Rural do Rio de Janeiro (UFRRJ) in the municipality of Seropédica, Rio de Janeiro.

A hemolymph screen was performed on 50 engorged females collected after completing their second generation on the infested animal in UFRRJ. The specimens were placed in Petri dishes and fixed in plaster with the ventral region facing upwards. During the non-parasitic phase, the ticks were kept in an incubator at $27 \pm 1{ }^{\circ} \mathrm{C}$ and a relative humidity above $80 \%$.

On the 8th day of oviposition, hemolymph smears were generated by sectioning the distal region of the first legs of each tick. Hemolymph was dispersed on a 12-cell screen-printed slide for individual evaluation. The hemolymph smears were fixed in methanol and stained with 10\% Giemsa and examined under an optical microscope using a 100x oil-immersion objective.

\section{Morphometric analysis}

The morphometric analysis of the spiral forms was performed by optical microscopy using the oil-immersion objective, with a coupled photo documentation system (D 'Cell software - Olympus ${ }^{\circledR}$ ). The evaluated parameters were a diameter, total length, and number of spirals for each form.

\section{Molecular analysis}

Females that were positive for spiral forms in the smear, their eggs, and the infested bovine blood collected 15 days after tick feeding were submitted for molecular analysis. DNA extraction was performed using a commercial Dneasy ${ }^{\circledR}$ tissue kit (Qiagen ${ }^{\circledR}$ ) following the protocol recommended by the manufacturer.

Amplification of DNA fragments of three Borrelia genes was attempted by PCR. For the Glycerophosphodiester Phosphodiesterase gene $(g l p Q)$, reactions were performed using primers GlpQ F+1 (5'-GGGGTTCTGTTACTGCTAGTGCCATTAC3') and GlpQ F-1
(5'-CAATTTTAGATATGTCTTTACCTTGTTGTTTATGCC-3') and for the hypoxanthine-guanine phosphoribosyltransferase gene $(h p t)$ were performed using primers hptdegF (5'-GCAGAYATTACAAGAGARATGG-3') and hptdegR (5'-CYTCRTCACCCCATTGAGTTCC-3'). For the flagellin $\mathrm{B}$ gene $(f a B)$ reactions were performed using primers FlaLL (5'-ACATATTCAGATGCAGACAGAGGT-3') and FlaRL (5'-GCAATCATAGCCATTGCAGATTGT-3') (MCCOY et al., 2014).

The PCR mixtures contained $1.0 \mathrm{U}$ of GoTaq ${ }^{\circledR}$ DNA Polymerase (Promega ${ }^{\circledR}$, Brazil), 1x Green GoTaq ${ }^{\circledR}$ Reaction Buffer, $1.5 \mathrm{mM} \mathrm{MgCl}_{2}, 0.2 \mathrm{mM}$ dNTPs, 1.25 pmoles of each primer and $2.5 \mu \mathrm{l}$ of DNA template. Samples were initially heated to $95{ }^{\circ} \mathrm{C}$ for $5 \mathrm{~min}$ to denature the template and activate the polymerase, followed by 40 cycles of denaturation at $95^{\circ} \mathrm{C}$ for 60 seconds, annealing at $55^{\circ} \mathrm{C}($ flaB $), 53^{\circ} \mathrm{C}(h p t)$ or $57^{\circ} \mathrm{C}(g l p Q)$ for 60 seconds, and extension at $72{ }^{\circ} \mathrm{C}$ for 60 seconds, followed by a final extension at $72{ }^{\circ} \mathrm{C}$ for five minutes.

PCR products were analyzed by gel electrophoresis (1.5\% agarose). For each reaction, one positive (DNA of Borrelia anserina strain AL) and two negative controls (water) were included in the reaction.

\section{Sequencing and phylogenetic analysis}

PCR products of the expected size were purified using a PuriLink ${ }^{\circledR}$ PCR purification kit (Life Technology ${ }^{\circledR}$ ) and sequenced using a capillary-type Sanger platform in an ABI 3730 DNA Analyzer (Applied Biosystems, Life Technologies ${ }^{\circledR}$ ). The sequences generated were compared to published data using the NCBI Nucleotide BLAST program. Multiple sequence alignments were performed with sequences obtained from this study and sequences from GenBank using MUSCLE, in the SeaView v.4 program (GOUY et al., 2010). The best-fit evolutionary model was determined using jModelTest version 2.0 (DARRIBA et al., 2012). The Borrelia phylogenetic tree was constructed by the maximum likelihood method with MEGA 7 (KUMAR et al., 2016). The support for the tree nodes was measured using a heuristic search with 1000 bootstrap replicates.

\section{Results}

Of the 50 hemolymph smears of engorged female $R$. microplus ticks analyzed, only one was positive, thus indicating a $2 \%$ infection rate. Microscopic analysis of Giemsa-stained smears illustrated a typical morphology for Borrelia spp. (Figure 1). Free forms were observed in the hemolymph (Figure 1A-E) and forms in contact with the surface of the hemocytes (Figure 1C, E and F). In total, 50 spirochetes were identified across all fields of the hemolymph smears. The spirochete detected is herein referred to as B. theileri strain C5. The average number of spirals, length, and diameter of 43 spirochetes measured in thick hemolymph smears is shown in Table 1. Longer spirochetes (greater than $27 \mu \mathrm{m}$ ) were suspected to be in the process of dividing or attached to another spirochete in tandem.

The engorged female $R$. microplus ticks hemolymph positive, and their egg sample was positive for Borrelia by PCR. From the flaB, $g l p Q$ and $h p t$ PCRs, gene fragments of 593 bp, 548 bp and 389 bp were generated, respectively. No PCR products were amplified from the DNA in blood samples of the infested cattle. The sequences 


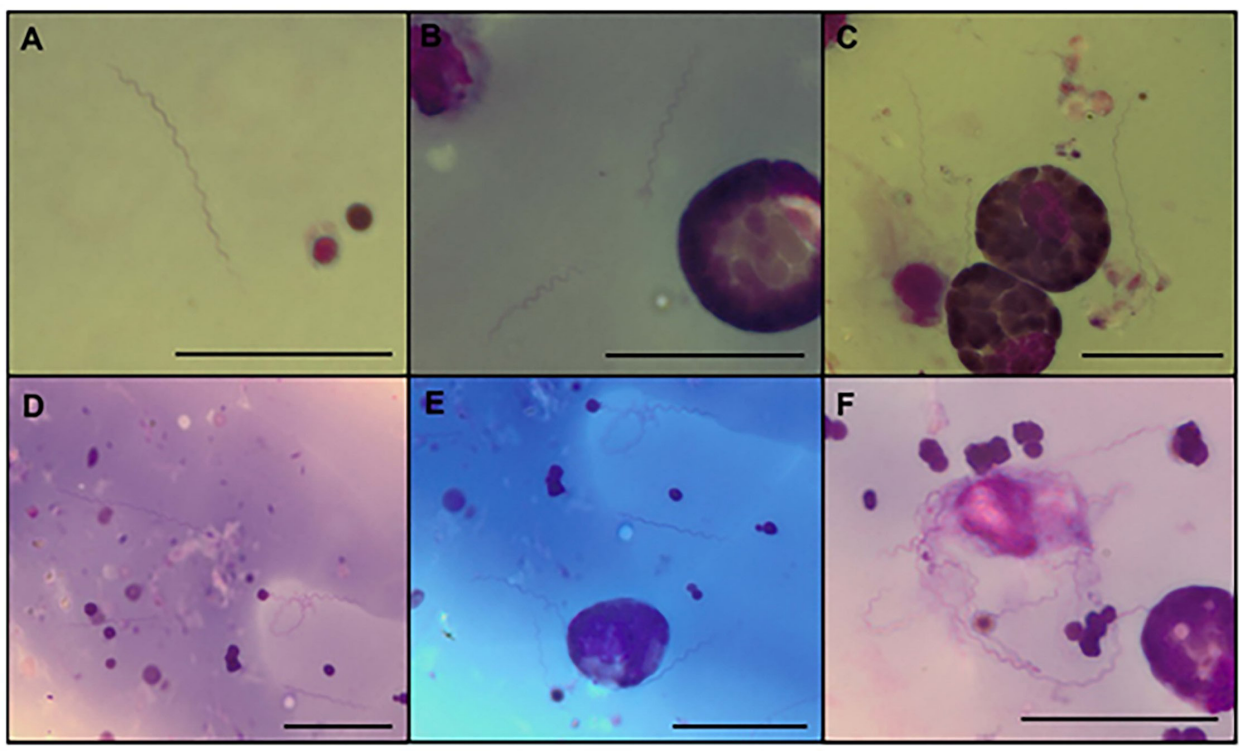

Figure 1. Typical forms of Borrelia theileri in hemolymph smears of Rhipicephalus microplus (A-F). Giemsa. Scale bar: $20 \mu \mathrm{m}$.

Table 1. Morphometric data $(\mu \mathrm{m})$ for spirochetes forms of Borrelia theileri strain C5 and published data from other Borreliae species.

\begin{tabular}{|c|c|c|c|c|c|c|}
\hline Species & Country & Host & $\begin{array}{c}\text { Length } \\
\text { Mean } \pm \mathrm{SD}^{*}(\mu \mathrm{m}) \\
(\text { Minimum- } \\
\text { Maximum) }\end{array}$ & $\begin{array}{c}\text { Diameter } \\
\text { Mean } \pm \text { SD }(\mu \mathrm{m}) \\
(\text { Minimum- } \\
\text { Maximum) }\end{array}$ & $\begin{array}{l}\text { Spiral numbers } \\
\text { Mean } \pm \text { SD } \\
\text { (Minimum- } \\
\text { Maximum) }\end{array}$ & References \\
\hline $\begin{array}{l}\text { Borrelia theileri } \\
\text { strain C5 }\end{array}$ & Brazil & Rhipicephalus microplus & $\begin{array}{c}19.17 \pm 4.12 \\
(10.34-26.84)\end{array}$ & $\begin{array}{c}0.2935 \pm 0.0469 \\
(0.20-0.31)\end{array}$ & $\begin{array}{c}8.44 \pm 2.59 \\
\quad(5-11)\end{array}$ & This study \\
\hline Borrelia theileri & Brazil & Rhipicephalus microplus & $\begin{array}{l}\mathrm{ND}^{* *} \\
(10-19)\end{array}$ & ND & ND & Martins et al. (1996) \\
\hline Borrelia theileri & Mexico & Rhipicephalus microplus & $17.66 \pm 0.46$ & ND & ND & Smith et al. (1978) \\
\hline Borrelia theileri & Mexico & Bovine & $11.65 \pm 0.58$ & ND & ND & Smith et al. (1978) \\
\hline Borrelia theileri & Botswana & Bovine & $\begin{array}{c}13.2 \\
(9-18.5)\end{array}$ & ND & Numerous & Sharma et al. (2000) \\
\hline Borrelia theileri & Australia & Bovine & $\begin{array}{c}12.1 \\
(6-19.5)\end{array}$ & ND & $\begin{array}{l}\text { ND } \\
(3-7)\end{array}$ & Callow (1967) \\
\hline Borrelia theileri & Australia & Rhipicephalus microplus & $\begin{array}{c}\text { ND } \\
(8.3-18.3)\end{array}$ & ND & $\begin{array}{l}\mathrm{ND} \\
(4-8)\end{array}$ & Callow (1967) \\
\hline Borrelia theileri & South Africa & Bovine & $\begin{array}{c}13.2 \\
(9.6-18.9)\end{array}$ & ND & $\begin{array}{l}\text { ND } \\
(3-7)\end{array}$ & Callow (1967) \\
\hline Borrelia theileri & South Africa & Equine & $\begin{array}{c}5.7 \\
(3.5-9)\end{array}$ & ND & $\begin{array}{l}\text { ND } \\
(1-3)\end{array}$ & Callow (1967) \\
\hline Borrelia lonestari & United States & Culture & $\begin{array}{l}15.48 \\
(11-25)\end{array}$ & ND & ND & Varela et al. (2004) \\
\hline Borrelia turcica & Turkey & Hyalomma aegyptium & $\begin{array}{c}\text { ND } \\
(10-25)\end{array}$ & $\begin{array}{c}\text { ND } \\
(0.2-0.28)\end{array}$ & ND & Güner et al. (2003) \\
\hline
\end{tabular}

${ }^{*} \mathrm{SD}=$ Standard Deviation; ${ }^{* *} \mathrm{ND}=$ Not determined

generated from the PCR-amplified genes were analyzed to determine the similarity to other species in the GenBank Nucleotide database. The partial sequence of the $f l a B$ gene showed $100 \%$ coverage and $99 \%$ similarity to that of $B$. theileri strain KAT (access number KF569936). It also showed 99\% similarity and 99\% coverage with sequences of Borrelia sp. strain BR (access number EF141022). For the $g l p Q$ gene, there was $98 \%$ similarity to $B$. theileri strain KAT (query coverage $99 \%$ ) and $100 \%$ similarity to Borrelia sp. BR (query coverage $57 \%$ ). The PCR products of the $h p t$ gene aligned with $99 \%$ of the query sequence (query coverage $91 \%$ ) of $B$. theileri strain KAT and $90 \%$ of the query sequence (query coverage of
99\%) of B. miyamotoi strain CT13-2396. The novel sequences were deposited in the GenBank with the following accession numbers MG601737 (flaB), MG601738 ( $g l p Q)$ and MG601739 (hpt).

The phylogenetic relationship analysis based on the $f a B, g l p Q$ and $h p t$ gene sequences obtained in this study formed a clade highly related to $B$. theileri strain KAT, which was well-supported as being monophyletic (Figures 2, 3 and 4). In the phylogenetic tree of the $f l a B$ gene, the clade included Borrelia sp. strain BR, followed by the sequence obtained from this study and $B$. theileri strain KAT (Figure 2). 


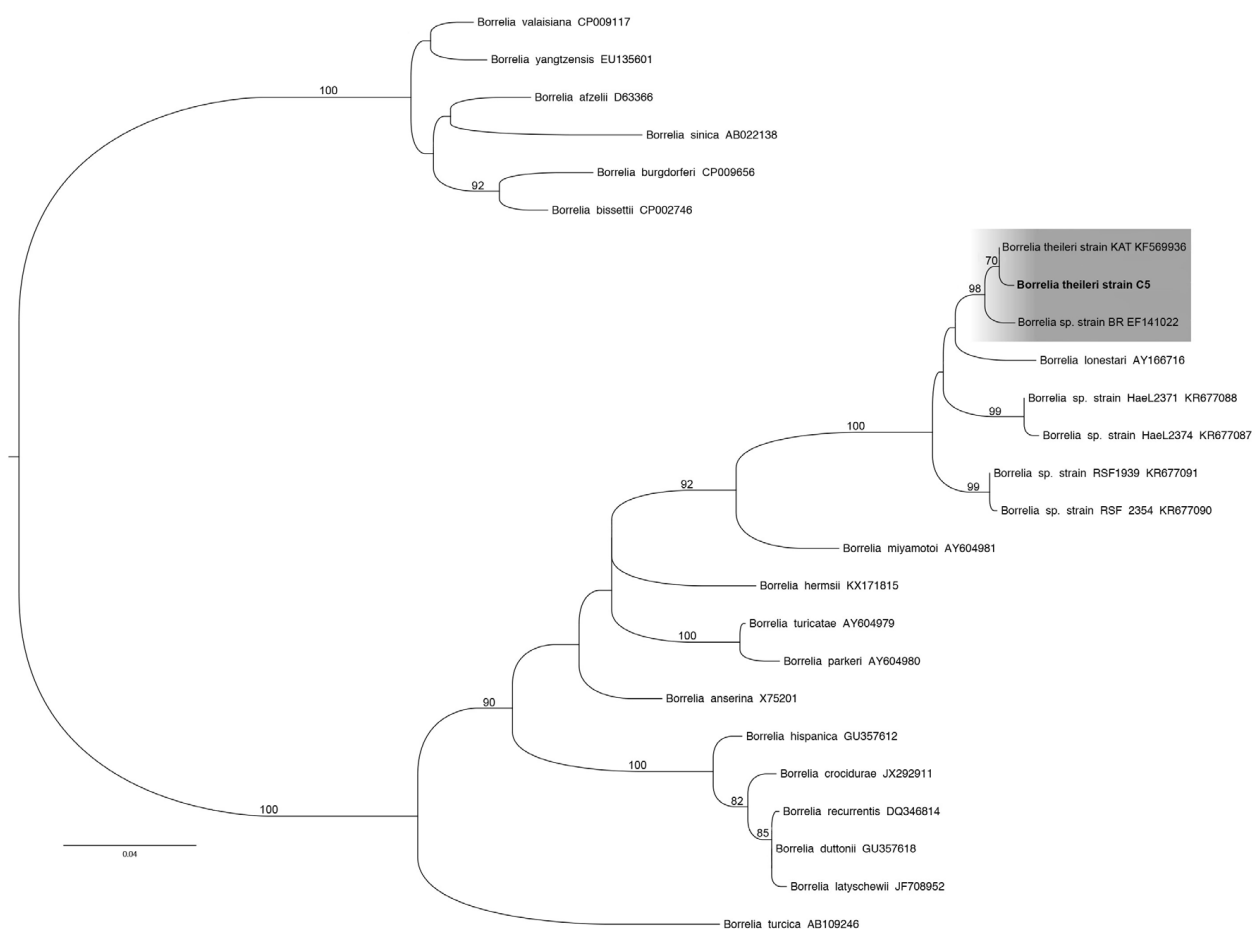

Figure 2. Phylogenetic relationships between Borrelia based on maximum likelihood analysis generated from comparisons of a 497 bp fragment of the $f a B$ sequence. The scale bars indicate an evolutionary distance of 0.04 substitutions per position in the sequence. The numerical value $\geq 0.7$ at the node indicates the bootstrap replicates supported by the inner branch. The branch labels include GenBank accession numbers. The Tamura 3-parameter model with gamma-distributed heterogeneity $(\mathrm{T} 92+\mathrm{G})$ was selected as the best-fit evolutionary model.

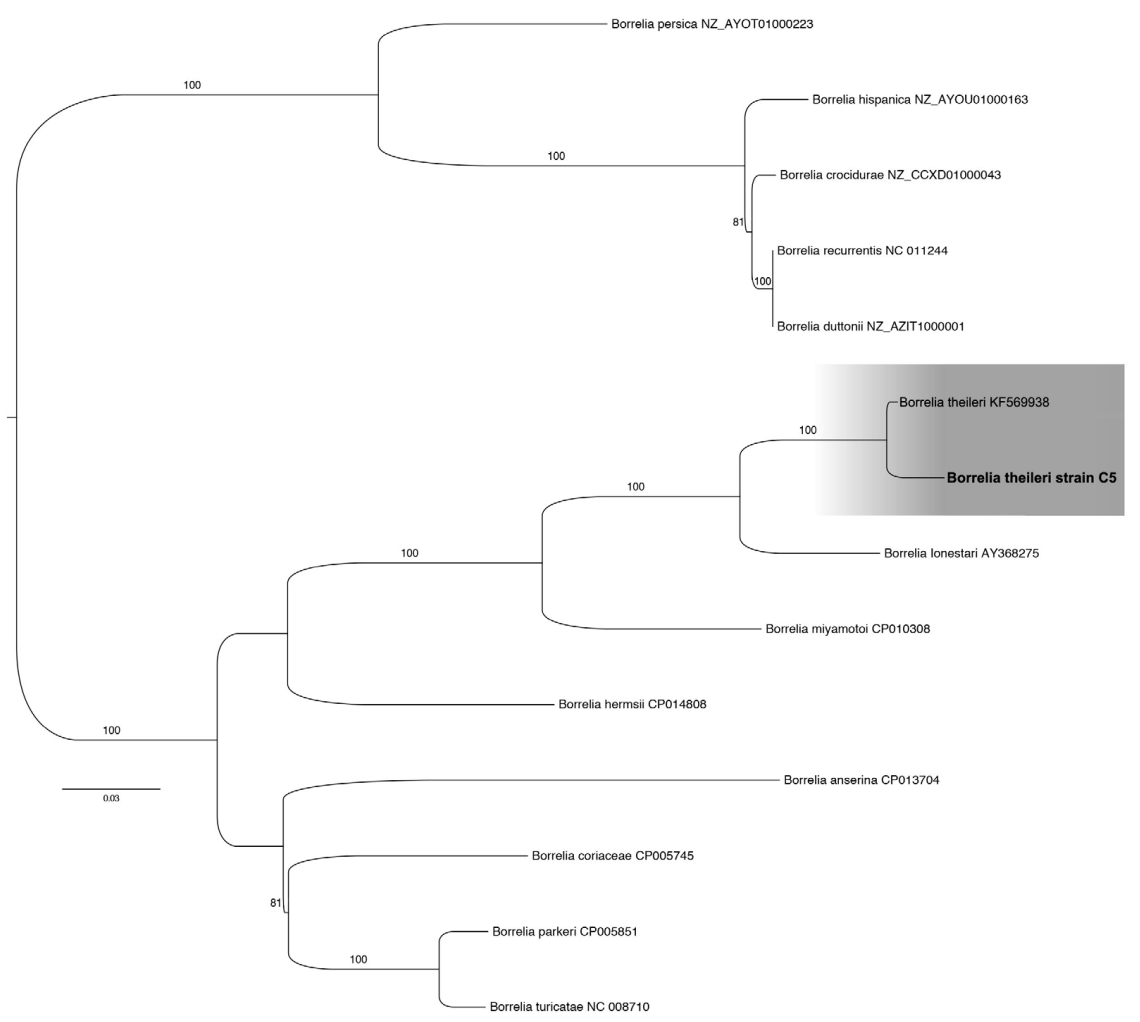

Figure 3. Phylogenetic relationships between Borrelia based on maximum likelihood analysis generated from comparisons of a 548 bp fragment of $g l p Q$ sequences. The scale bars indicate an evolutionary distance of 0.03 substitutions per position in the sequence. The numerical value $\geq 0.7$ at the node indicates the bootstrap replicates supported by the inner branch. The branch labels include GenBank accession numbers. The General Time Reversible model with gamma-distributed heterogeneity (GTR + G) was selected as the best-fit evolutionary model. 


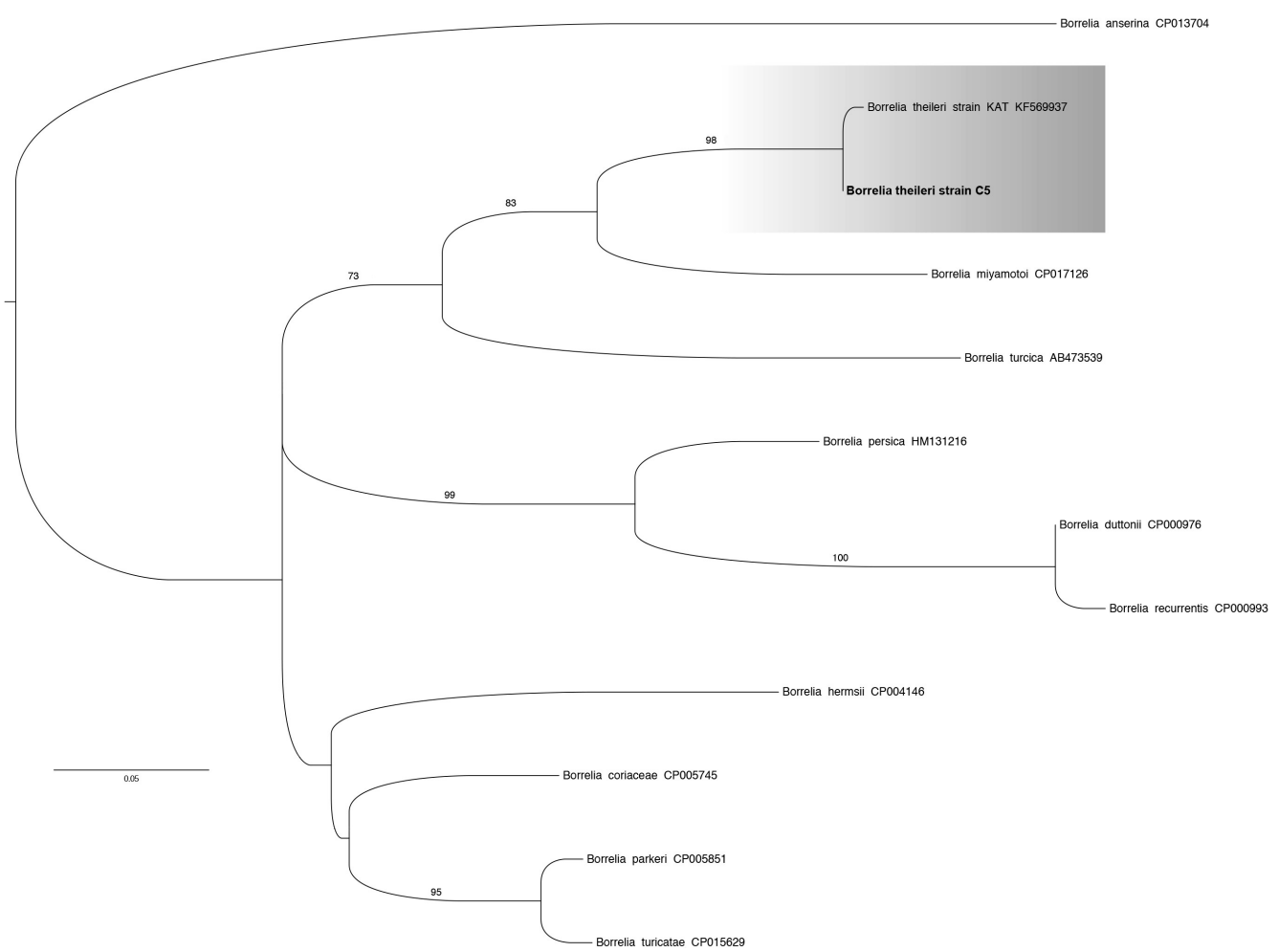

Figure 4. Phylogenetic relationships between Borrelia based on maximum likelihood analysis generated from comparisons of a $382 \mathrm{bp}$ fragment of $h p t$ sequences. The scale bars indicate an evolutionary distance of 0.05 substitutions per position in the sequence. The numerical value $\geq 0.7$ at the node indicates the bootstrap replicates supported by the inner branch. The branch labels include GenBank accession numbers. The General Time Reversible model with gamma-distributed heterogeneity $(\mathrm{GTR}+\mathrm{G})$ was selected as the best-fit evolutionary model.

\section{Discussion}

This study presents the most complete description of $B$. theileri in $R$. microplus in the Americas to-date and includes molecular data and some morphological data regarding $B$. theileri in $R$. microplus ticks, in addition to the detection of transovarial transmission (TOT).

The description of this spirochete in $R$. microplus ticks in South America was made only by incidental findings in hemolymph smears (MARTINS et al., 1996; SOARES et al., 2000). In addition to these findings, Yparraguirre et al. (2007) reported a molecular isolate of Borrelia sp. BR in the Southeastern region of Brazil. However, the scarcity of molecular data for $B$. theileri meant that there was insufficient evidence for accurate identification of the species. However, the alignment of its sequences with $B$. theileri strain KAT and two other sequences of $B$. theileri from GenBank possibly identify this spirochete as $B$. theileri species (MCCOY et al., 2014).

The infection rate identified in our study (2\%) was relatively higher than reported in other studies (MARTINS et al., 1996; YPARRAGUIRRE et al., 2007) and (MCCOY et al., 2014) Although the infested animal in this study was negative by PCR, it is possible that it was the source of infection for the positive tick, since $B$. theileri is usually in low parasitemia (CALLOW, 1967) and therefore would have infected only one of the 50 R. microplus females.
McCoy et al. (2014) observed that only one of six Rhipicephalus spp. from the same animal was positive for $B$. theileri by PCR.

In general, clinical signs of infection in cattle and other animals are mild and variable, but during the latent phase of infection transient increases in rectal temperature up to $39.5^{\circ} \mathrm{C}$ and occasional mild depression with anorexia and anemia are observed (MCCOY et al., 2014).

In our study, TOT was observed through PCR amplification of $B$. theileri genes. These results corroborate Smith et al. (1978) who visualized spirochetes on eggs of $R$. microplus females infected with $B$. theileri. In addition, Smith et al. (1978) reported that the bacterium was observed in ovaries, central ganglia and hemolymph, with intense multiplication occurring in hemocytes. In contrast, Martins et al. (1996) were unable to visualize B. theileri in macerated eggs from the infected female. Rollend et al. (2013) reported the occurrence of TOT of B. miyamotoi, the relapsing fever group spirochete in Ixodes scapularis. The study evaluated many I. scapularis tick progenies providing strong evidence that B. burgdorferi sensu stricto TOT does not occur in I. scapularis.

The morphometric analysis of $B$. theileri strain C5 (Table 1) displays variation in the size and number of spirals, similar to that observed in the other studies of $B$. theileri presented in the table. It is important to emphasize; however, that organisms of this genus reproduce by transverse fission, which requires 
elongation of the form and can produce variation in form length (VARELA et al., 2004).

Schwarzbach et al. (2015) demonstrated that B. burgdorferi pleomorphism is related to the cultivation conditions, which produces forms ranging from typical (elongated and spiraled) to round bodies. The authors also observed that each morphological variant has distinct biochemical markers, which could influence the pathogenesis of Lyme disease. Here, although B. theileri showed a wide variation in the length and number of spirals, there was no pleomorphism such as described by Schwarzbach et al. (2015). This lack of pleomorphism may be due to being isolated from a single tick, or this accentuated pleomorphism may not be a characteristic of $B$. theileri.

When first isolating $B$. lonestari in the ISE6 cell line of I. scapularis, Varela et al. (2004) demonstrated an intimate relationship between the bacterium and the ISE6 cell membrane by electron microscopy, suggesting a process of interaction between $B$. lonestari and this cell line.

In this study, some spirochetes were in contact with the hemocyte surface of the tick (Figure 1C, E and F), even in great abundance (Figure $1 \mathrm{~F}$ ), suggesting that there may also be an interaction between $B$. theileri and the tick cell. Thus, the methodology used by Varela et al. (2004) may be a candidate approach for a future study of this species.

Phylogenetic analyses of $f l a B, h p t$ and $g l p Q$ revealed that the sequences generated in this study clearly formed a cluster highly related to other $B$. theileri sequences in GenBank, including Borrelia sp. strain BR. This result definitively confirms the circulation of this species of Borrelia in South America.

Combining the morphometric and phylogenetic data (but without molecular evaluation), we believe that the spirochete parasitizing the hemolymph of $R$. microplus females in the American continent belongs to the species $B$. theileri. In Brazil, spirochetes are suspected of causing disease in humans. The $R$. microplus tick is among the possible ixodid species involved in the transmission of this bacterium (YOSHINARI et al., 2010). However, to-date, $B$. theileri has only been found in cattle, horses, goats and sheep (CALLOW, 1967) and there is no record of infection in humans. Nonetheless, as presented in the phylogenetic analysis, $B$. theileri is highly related to $B$. lonestari and $B$. miyamoto $i$ two spirochetes of the relapsing fever group involved in human disease (VARELA et al., 2004; ROLLEND et al., 2013). In addition, the pathogenicity of each strain may vary, as we clearly observe a genetic difference between the different isolates, thus justifying the need for studies of the possible involvement of $B$. theileri in the etiology of the disease in Brazil.

\section{Acknowledgements}

To Dr. Itabajara da Silva Vaz Junior of the Universidade Federal do Rio Grande do Sul for provide the Porto Alegre tick strain. To the Conselho Nacional de Desenvolvimento Científico e Tecnológico (CNPq), Fundação Carlos Chagas Filho de Amparo à Pesquisa do Estado do Rio de Janeiro (FAPERJ) and to the Coordenação de Aperfeiçoamento de Pessoal de Nível Superior) (CAPES), for their financial support.

\section{References}

Callow LL. Observations on tick-transmitted spirochaetes of cattle in Australia and South Africa. Br Vet J 1967; 123(11): 492-497. http:// dx.doi.org/10.1016/S0007-1935(17)39704-X. PMid:6070621.

Darriba D, Taboada GL, Doallo R, Posada D. Model Test 2: more models, new heuristics and parallel computing. Nat Methods 2012; 9(8): 772 http://dx.doi.org/10.1038/nmeth.2109. PMid:22847109.

Gouy M, Guindon S, Gascuel O. SeaView version 4: a multiplatform graphical user interface for sequence alignment and phylogenetic tree building. Mol Biol Evol 2010; 27(2): 221-224. http://dx.doi.org/10.1093/ molbev/msp259. PMid:19854763.

Guedes DS Jr, Araújo FR, Silva FJM, Rangel CP, Barbosa JD No, Fonseca AH. Frequency of antibodies to Babesia bigemina, B. bovis, Anaplasma marginale, Trypanosoma vivax and Borrelia burdgorferi in cattle from the northeastern region of the state of Pará, Brazil. Rev Bras Parasitol Vet 2008; 17(2): 105-109. http://dx.doi.org/10.1590/S1984-29612008000200008. PMid:18823579.

Güner ES, Hashimoto N, Kadosaka T, Imai Y, Masuzawa T. A novel, fastgrowing Borrelia sp. isolated from the hard tick Hyalomma aegyptium in Turkey. Microbiology 2003; 149(9): 2539-2544. http://dx.doi.org/10.1099/ mic.0.26464-0. PMid:12949178.

Kumar S, Stecher G, Tamura K. MEGA7: molecular evolutionary genetics analysis version 7.0 for bigger datasets. Mol Biol Evol 2016; 33(7): 18701874. http://dx.doi.org/10.1093/molbev/msw054. PMid:27004904.

Martins JR, Ceresér VH, Corrêa BL, Smith RD. Borrelia theileri: observação em carrapatos do gênero Boophilus microplus no município de Guaíba, RS, Brasil. Cienc Rural 1996; 26(3): 447-450. http://dx.doi. org/10.1590/S0103-84781996000300018.

McCoy BN, Maiga O, Schwan TG. Detection of Borrelia theileri in Rhipicephalus geigyi from Mali. Ticks Tick Borne Dis 2014; 5(4): 401403. http://dx.doi.org/10.1016/j.ttbdis.2014.01.007. PMid:24709337.

Reck J Jr, Berger M, Terra RMS, Marks FS, da Silva Vaz I Jr, Guimarães JA, et al. Systemic alterations of bovine hemostasis due to Rhipicephalus (Boophilus) microplus infestation. Res Vet Sci 2009; 86(1): 56-62. http:// dx.doi.org/10.1016/j.rvsc.2008.05.007. PMid:18571684.

Rogers AB, Smith RD, Kakoma I. Serologic cross-reactivity of antibodies against Borrelia theileri, Borrelia burgdorferi, and Borrelia coriaceae in cattle. Am J Vet Res 1999; 60(6): 694-697. PMid:10376894.

Rollend L, Fish D, Childs JE. Transovarial transmission of Borrelia spirochetes by Ixodes scapularis: a summary of the literature and recent observations. Ticks Tick Borne Dis 2013; 4(1-2): 46-51. http://dx.doi. org/10.1016/j.ttbdis.2012.06.008. PMid:23238242.

Schwarzbach A, Herranen A, Gilbert L, Meriläinen L. Morphological and biochemical features of Borrelia burgdorferi pleomorphic forms. Microbiology 2015; 161(3): 516-527. http://dx.doi.org/10.1099/ mic.0.000027. PMid:25564498.

Sharma SP, Amanfu W, Losho TC. Bovine borreliosis in Botswana. Onderstepoort J Vet Res 2000; 67(3): 221-223. PMid:11131124.

Smith RD, Brener J, Osorno M, Ristic M. Pathobiology of Borrelia theileri in the tropical cattle tick, Boophilus microplus. J Invertebr Pathol 1978; 32(2): 182-190. http://dx.doi.org/10.1016/0022-2011(78)900289. PMid:731072. 
Soares CO, Ishikawa MM, Fonseca AH, Yoshinari NH. Borrelioses, agents and vectors: a review. Pesq Vet Bras 2000; 20(1): 1-19. http:// dx.doi.org/10.1590/S0100-736X2000000100001.

Varela AS, Luttrell MP, Howerth EW, Moore VA, Davidson WR, Stallknecht DE, et al. First culture isolation of Borrelia lonestari, putative agent of southern tick-associated rash illness. J Clin Microbiol 2004; 42(3): 1163-1169. http://dx.doi.org/10.1128/JCM.42.3.1163-1169.2004. PMid:15004069.
Yoshinari NH, Mantovani E, Bonoldi VL, Marangoni RG, Gauditano G. Doença de lyme- símile brasileira ou síndrome baggio yoshinari: zoonose exótica e emergente transmitida por carrapatos. Rev Assoc Med Bras 2010; 56(3): 363-369. http://dx.doi.org/10.1590/S0104-42302010000300025. PMid:20676548.

Yparraguirre LA, Machado-Ferreira E, Ullmann AJ, Piesman J, Zeidner NS, Soares CAG. A hard tick relapsing fever group spirochete in a Brazilian Rhipicephalus (Boophilus) microplus. Vector Borne Zoonotic Dis 2007; 7(4): 717-721. http://dx.doi.org/10.1089/vbz.2007.0144. PMid:17979536. 